\title{
Intruder Scenarios for Site-Specific Low-Level Radioactive Waste Classification
}

\author{
W. E. Kennedy, Jr. \\ R. A. Peloquin
}

September 1988 


\section{DISCLAIMER}

This report was prepared as an account of work sponsored by an agency of the United States Government. Neither the United States Government nor any agency Thereof, nor any of their employees, makes any warranty, express or implied, or assumes any legal liability or responsibility for the accuracy, completeness, or usefulness of any information, apparatus, product, or process disclosed, or represents that its use would not infringe privately owned rights. Reference herein to any specific commercial product, process, or service by trade name, trademark, manufacturer, or otherwise does not necessarily constitute or imply its endorsement, recommendation, or favoring by the United States Government or any agency thereof. The views and opinions of authors expressed herein do not necessarily state or reflect those of the United States Government or any agency thereof. 


\section{DISCLAIMER}

Portions of this document may be illegible in electronic image products. Images are produced from the best available original document. 
W. E. Kennedy, Jr.

R. A. Peloquin

September 1988

Prepared for

the U.S. Department of Energy Idaho Operations office under Contract DE-AC07-76ID01570

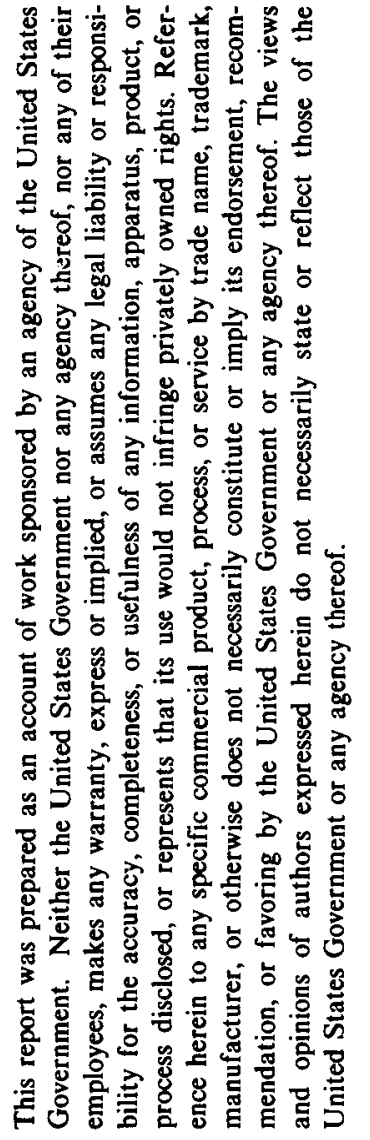

\section{This document is} PUBLICLY RELEASABLE Lasy Eohas 

The U.S. Department of Energy (DOE) has revised its low-level radioactive waste (LLW) management requirements and guidelines for waste generated at its facilities supporting defense missions. Specifically, draft DOE Order 5820.2A, Chapter III, a describes the purpose, policy, and requirements necessary for the management of defense LLW. The draft DOE policy calls for LLW operations to be managed to protect the health and safety of the public, preserve the environment, and ensure that no remedial action will be necessary after termination of operations. The basic approach used by DOE is to establish overall performance objectives, in terms of groundwater protection and public radiation dose limits, and to require site-specific performance assessments to determine compliance. As a result of these performance assessments, each site will develop waste acceptance criteria that define the allowable quantities and concentrations of specific radioisotopes. Additional limitations on waste disposal design, waste form, and waste treatment will also be developed on a site-specific basis. As a key step in the site-specific performance assessments, an evaluation must be conducted of potential radiation doses to intruders who may inadvertently move onto a closed DOE LLW disposal site after loss of institutional controls. This report (1) describes the types of intruder scenarios that should be considered when performing this step of the sitespecific performance assessment, (2) provides the results of generic calculations performed using unit concentrations of various radionuclides as a comparison of the magnitude of importance of the various intruder scenarios, and (3) shows the relationship between the generic doses and waste classification limits for defense wastes.

a. U.S. Department of Energy, Radioactive Waste Management, DRAFT DOE Order $5820.2 A(5 / 11 / 88)$, Washington, D.C. 
. 


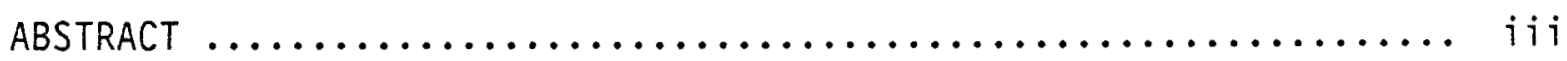

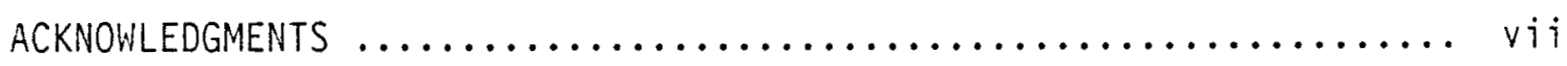

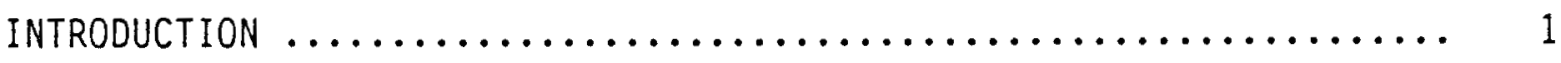

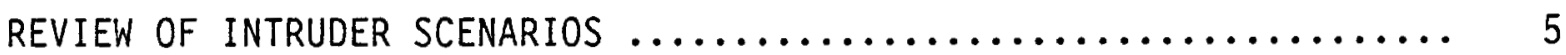

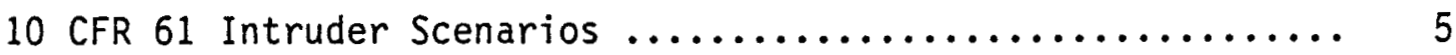

Intruder-Construction Scenario $\ldots \ldots \ldots \ldots \ldots \ldots \ldots \ldots \ldots, 5$

Intruder-Agriculture Scenario .................... 9

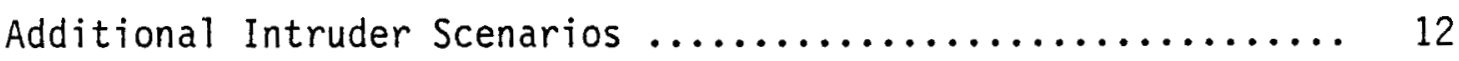

Drilling Scenario ........................... 12

Post-Drilling Scenario ......................... 13

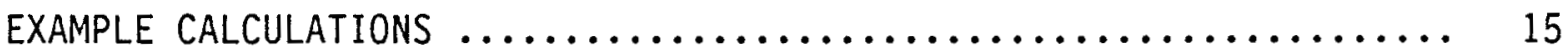

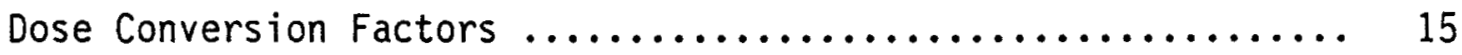

NRC Pathway Dose Conversion Factors $\ldots . \ldots \ldots \ldots \ldots \ldots .15$

DOE Internal Dose Conversion Factors $\ldots . \ldots \ldots \ldots \ldots \ldots .18$

Example Unit Dose Calculations ........................ 18

Example Generic Waste Classification $\ldots \ldots \ldots \ldots \ldots \ldots \ldots \ldots .22$

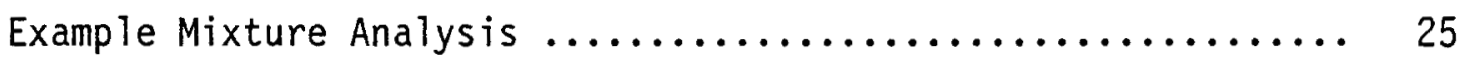

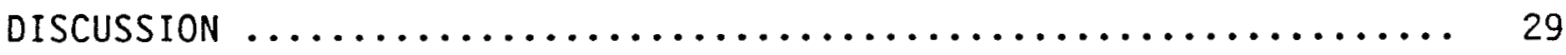

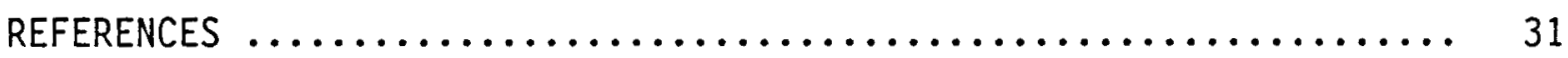




\section{FIGURES}

1 Intruder-construction basement excavation volume

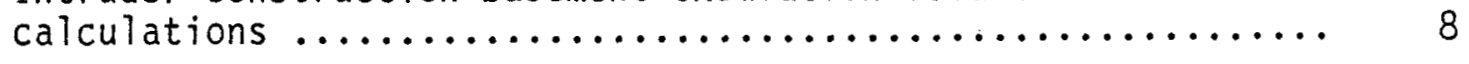

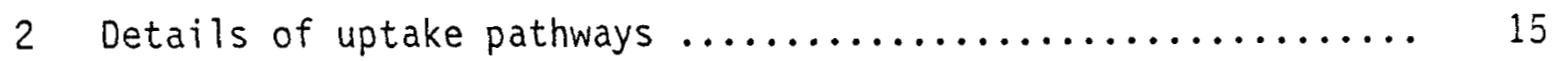

\section{TABLES}

1 SCENARIO ASSUMPTIONS AND PARAMETER VALUES USED FOR SETTING THE 10 CFR 61 CLASS A AND C WASTE CLASSIFICATION LIMITS ...... 7

2 ACCESS LOCATION-TO-HUMAN PATHWAY DESCRIPTIONS $\ldots \ldots \ldots \ldots \ldots . . . . .17$

3 DOSE PER UNIT CONCENTRATION EXAMPLE RESULTS FOR INTRUSION 100 YEARS AFTER SITE CLOSURE, REM/YR PER CI/M 3 ............. 20

4 DOSE PER UNIT CONCENTRATION EXAMPLE RESULTS FOR INTRUSION 500 YEARS AFTER SITE CLOSURE, REM/YR PER CI/M3 $\ldots \ldots \ldots \ldots \ldots .21$

5 EXAMPLE WASTE CLASSIFICATION BY SCENARIO FOR INTRUSION AT

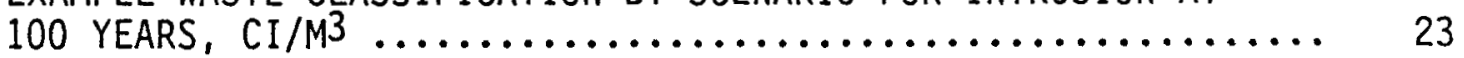

6 EXAMPLE WASTE CLASSIFICATION FOR INTRUSION-PROTECTED WASTES

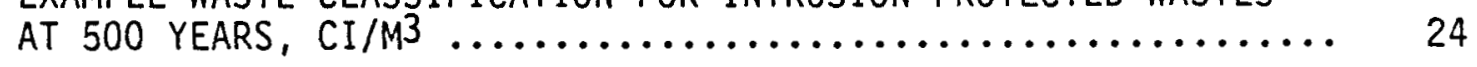

7 EXAMPLE CALCULATIONS FOR A REFERENCE WASTE MIXTURE USING THE EXAMPLE WASTE CLASSIFICATION LIMITS $\ldots \ldots \ldots \ldots \ldots$

8 EXAMPLE CALCULATIONS FOR A REFERENCE WASTE MIXTURE USING THE GENERIC EXAMPLE WASTE CLASSIFICATION LIMITS 


\section{ACKNOWLEDGMENTS}

The authors would like to thank all of those individuals who helped contribute to the development, production, and publication of this report. We greatly appreciate the preliminary technical development efforts of Bill Farris, the guidance, review, and encouragement provided by joe soldat and Bruce Napier, and the typing support provided by Carolyn Schauls. 


\section{INTRODUCTION}

In support of revised U.S. Department of Energy (DOE) Orders on low-level radioactive waste (LLW) management, a special working group was established by the Defense LLW Management Program managed by the Idaho National Engineering Laboratory (INEL). During a meeting held on May 7-8, 1987, the working group reviewed the draft DOE approach to waste classification and established overall performance objectives. These performance objectives define the basic standards that serve as the primary regulation for defense LLW disposal with in the scope of the DOE Order. The performance objectives developed by the working group included protection of (1) workers and the public during site operation (consistent with other DOE Orders), (2) intruders who may inadvertently move onto a closed DOE LLW disposal site after loss of institutional controls (100 years after site closure), (3) members of an offsite population group, and (4) water resources by means of enforcing of applicable standards. These performance objectives have been revised and included in DOE Order 5820.2A, Chapter III, as follows: a

- Protect public health and safety in accordance with standards specified in draft DOE Order $5400.3^{\mathrm{b}}$ and other DOE Orders.

- Ensure that external exposure to the waste, and exposures to concentrations of radioactive material which may be released into surface water. groundwater, soil, plants, and animals, result in an effective dose equivalent that does not exceed $25 \mathrm{mrem} / \mathrm{yr}$ to any member of the public. Releases to the atmosphere shall meet the requirements of 40 CFR 61.1 Reasonable effort should be made to maintain releases of radioactivity in effluents to the general environment as low as is reasonably achievable.

- Ensure that the effective dose equivalents received by individuals who inadvertently may intrude into the facility after the loss of active institutional control (100 years) will not exceed $100 \mathrm{mrem} / \mathrm{yr}$ for continuous exposure or $500 \mathrm{mrem} / \mathrm{yr}$ for a single acute exposure.

a. U.S. Department of Energy, Radioactive Waste Management, DRAFT DOE Order 5820.2A (6/21/88), Washington, D.C.

b. U.S. Department of Energy, Radiation Protection of the Public and Environment, DRAFT DOE Order 5400.3 (7/28/88), Washington, D.C. 
- Protect groundwater resources consistent with federal, state, and local requirements.

The requirements and guidelines in the DOE Order 5820.2A, Chapter III, are applicable to radioactive wastes but are also intended to apply to mixed wastes (radioactive wastes that have hazardous components) as defined in draft DOE Order 5400.5, "Hazardous and Radioactive Mixed Waste."a To determine compliance with these performance objectives, DOE Order 5820.2A, Chapter III, requires that the DOE field organizations with operating disposal sites prepare and maintain a site-specific radiological performance assessment. Radiological performance assessment is defined as "a systematic analysis of a LLW treatment, storage, or disposal facility and its local environment for purposes of demonstrating compliance with the performance objectives." It should be noted that this definition does not address the nonradiological components of LLW (because they are assumed to be covered under other DOE Orders), and it does not address worker protection.

The analysis of intruder scenarios during the performance assessment is useful in setting site-specific limits on waste concentration, whereas analysis of transport of radioactive material through groundwater is useful in setting site inventory limits. Concentration limits set by intruder scenarios are intended to be used along with practical consideration of the waste form and disposal design to establish site-specific waste classification systems. The steps in this part of the performance assessment include: (1) establishing the site-specific scenarios, parameters, and assumptions; (2) performing draft calculations for unit concentrations of selected radionuclides found in defense LLW; and (3) performing an "inverse-type" calculation to establish the waste concentrations that would be permitted at the time of burial so that the intruder dose performance objectives can be met at the assumed time of intrusion.

When considering human-intrusion scenarios, an effort should be made to match the scenarios with the site-specific disposal and waste form conditions encountered. This means that scenarios must be considered in addition to

a. U.S. Department of Energy, Hazardous and Radioactive Mixed Waste Management, DRAFT DOE Order 5400.5, 1988, Washington, D.C. 
those identified by the U.S. Nuclear Regulatory Commission (NRC) in their analysis supporting 10 CFR 61.3 A generic evaluation of similar scenarios was conducted for long-lived radionuclides by an Expert Group to the Nuclear Energy Agency of the Organization for Economic Cooperation and Development (NEA/OECD).4 The scenarios considered by the NRC and the NEA/OECD, and most scenarios involving human intrusion, are deterministic. This means that they are assumed to occur with no probability assigned to occurrence. It also means that each scenario may be controlled by additional key assumptions concerning the waste dilution and environmental transport. These assumptions may cause an overestimate or underestimate of the actual conditions in the future. However, this approach has been justified because of a lack of longterm performance data that would permit the use of more sophisticated probabilistic methods. Computerized models that permit the rapid calculation of radiation doses for a wide variety of intruder scenarios 5,6 are available from the NRC. The following sections provide a review of the generic humanintrusion scenarios used by the NRC, provide a review of additional scenarios that may be used to describe DOE site-specific waste disposal, present the results of example generic calculations using the scenarios, and provide example "inverse-type" results relating to waste classification. 
Intruder scenarios have been developed and applied in a number of previous national and international LLW assessments. Of particular note are the humanintrusion scenarios for near-surface wastes developed by the NRC in support of the commercial LLW classification system7 and additional scenarios for intruder-resistant wastes developed for the Hanford Defense Waste Environmental Impact Statement. 8 Because there will be some variability between waste forms, engineered systems, and environmental conditions at DOE LLW disposal sites, it is difficult to identify generic scenarios that are universally applicable to all sites. However, broad scenarios can be identified for further sitespecific consideration, with the understanding that they may be modified to include the best available site data. The following paragraphs describe the significant human-intrusion scenarios contained in previous references that should be considered when performing site-specific performance assessments for DOE defense wastes. Additional scenarios beyond those identified in this report may have to be further defined to account for the unique conditions encountered at real sites.

\section{CFR 61 Intruder Scenarios}

In developing the 10 CFR 61 waste classification system (Reference 3), the NRC considered three intruder scenarios that would result in human exposure. These scenarios are entitled: (1) Intruder-Construction, (2) Intruder-Discovery, and (3) Intruder-Agriculture. For setting their Class $A$ and $C$ waste classification limits, the more restrictive of scenarios 1 and 3 (by radionuclide) was used. Scenario 2 was used for setting the Class B limits. These scenarios are described in References 5 and 7 . The following paragraphs describe the Intruder-Construction and Intruder-Agriculture scenarios. No description of the Intruder-Discovery scenario is provided, because it is considered to be a subset of the Intruder-Construction scenario (i.e., only the exposure duration is altered).

Intruder-Construction Scenario

The NRC assumes that this scenario would occur after the shutdown of operations at a disposal facility. Institutional controls are assumed to break down (temporarily), and an intruder inadvertently constructs a house on 
the disposal facility. The major assumptions and parameter values used by the NRC for this scenario are summarized in Table 1 . The NRC assumes that the intruder contacts the disposed wastes while performing excavation work associated with the construction of a basement for a house (p. G-58 of Reference 7). This construction work is assumed to last for 500 working hours or the equivalent of a 3 -month construction period. The NRC represents the basement by a 3-m-deep hole with bottom surface area of $20 \mathrm{~m} \times 10 \mathrm{~m}\left(200 \mathrm{~m}^{2}\right)$ and a top surface area of $26 \mathrm{~m} \times 16 \mathrm{~m}\left(416 \mathrm{~m}^{2}\right)$, giving a 1:1 slope for the side of the excavation. The volume of the excavation is equal to $906 \mathrm{~m}^{2}$ as shown in Figure 1 (Reference 5). The NRC assumes that the cover material placed over the waste during disposal operations is $2 \mathrm{~m}$ thick, for a volume of $675 \mathrm{~m}^{3}$, or about $75 \%$ of the volume of the entire excavation. Of the remaining volume (232 $\mathrm{m}^{3}$ or the bottom 1-m layer in the excavation), a portion is assumed by the NRC to be decomposed waste, and a portion is assumed to be soil or other backfill mixed with the waste during disposal operations.

The equation describing human exposure for the intruder-construction scenario is given by the NRC as (p. G-58 of Reference 7):

$$
H=\sum_{n}\left(f_{O} f_{d} f_{W} f_{s}\right) \text { air } C_{W} P D C F-2+\sum_{n}\left(f_{O} f_{d} f_{W} f_{s}\right) D G C_{W} \text { PDCF-5 }
$$

where

$$
\begin{aligned}
H & =\text { the } 50 \text {-year dose commitment in mrem } \\
\text { PDCF-2 } & =\text { pathway dose conversion factor for air } \\
\text { PDCF-5 } & =\text { pathway dose conversion factor for direct gamma exposure } \\
C_{W} & =\text { the concentration of radionuclide, } n, \text { in the waste }
\end{aligned}
$$

The first term in the equation accounts for exposures resulting from suspended contaminated dust, and the second term accounts for direct exposure to penetrating radiation during the excavation. The factor $f_{0}$ is the time-delay factor to account for radioactive decay between the time of burial and the time of excavation. For Class $A$ and $B$ waste calculations, this time is assumed by the NRC to be 100 years, and for Class $C$ wastes it is assumed to be 500 years. This factor is the same for both the air and direct gamma pathways. 
TABLE 1. SCENARIO ASSUMPTIONS AND PARAMETER VALUES USED FOR SETTING THE 10 CFR 61 CLASS A AND C WASTE CLASSIFICATION LIMITS (Reference 7)

\begin{tabular}{|c|c|}
\hline Scenario/Parameter & NRC Value \\
\hline \multicolumn{2}{|l|}{ INTRUDER-CONSTRUCTION } \\
\hline $\begin{array}{l}\text { Exposure duration } \\
f_{d} \text { (air \& gamma) } \\
f_{s} \text { (gamma) } \\
f_{s} \text { (air) } \\
\text { Dust loading }\end{array}$ & $\begin{array}{l}500 \mathrm{~h} / \mathrm{yr} \\
0.5 \\
0.057(500 \mathrm{~h} / \mathrm{yr}) \\
2.01 \times 10^{-11} \\
0.565 \mathrm{mg} / \mathrm{m}^{3}\end{array}$ \\
\hline \multicolumn{2}{|l|}{ INTRUDER-AGRICULTURE } \\
\hline $\begin{array}{l}f_{d} \text { (all pathways) } \\
f_{w} \text { (food) } \\
f_{S} \text { (air) } \\
f_{s} \text { (food) } \\
f_{S} \text { (gamma) } \\
\text { Dust loading } \\
\text { Inhalation duration } \\
\text { Vegetable consumption } \\
\text { Meat consumption } \\
\text { Milk consumption } \\
\text { Cow grass consumption }\end{array}$ & $\begin{array}{l}4380 \mathrm{~h} / \mathrm{yr} \\
2000 \mathrm{~h} / \mathrm{yr} \\
250 \mathrm{~h} / \mathrm{yr} \\
330 \mathrm{~h} / \mathrm{yr} \\
100 \mathrm{~h} / \mathrm{yr} \\
1700 \mathrm{~h} / \mathrm{yr} \\
0.125 \\
1.0 \\
3.18 \times 10-11 \\
0.5 \mathrm{~h} \\
0.27(1670 \mathrm{~h} / \mathrm{yr}) \\
0.154 \mathrm{mg} / \mathrm{m}^{3} \\
6180 \mathrm{~h} / \mathrm{yr} \\
190 \mathrm{~kg} / \mathrm{yr} \\
95 \mathrm{~kg} / \mathrm{yr} \\
110 \mathrm{~L} / \mathrm{yr} \\
50 \mathrm{~kg} / \mathrm{d}\end{array}$ \\
\hline \multicolumn{2}{|l|}{ BOTH SCENARIOS } \\
\hline$f_{0}$ & $e^{-\lambda T}$ \\
\hline $\begin{array}{l}f_{W} \text { (air \& gamma) } \\
\text { Volume of excavation } \\
\text { Volume of waste } \\
\text { Volume of cover } \\
\text { Class C waste form } \\
\text { credit }\end{array}$ & $\begin{array}{l}1.0 \\
906 \mathrm{~m}^{3} \\
232 \mathrm{~m}^{3} \\
675 \mathrm{~m}^{3} \\
10\end{array}$ \\
\hline
\end{tabular}

3 -months of construction

Site design and operation factor

Site selection factor

Site selection factor

Dust concentration in air
At home
At work
Commuting
Vacation
Gardening
Outdoors
Site design and operation factor Waste form and package factor
Site selection factor
Site selection factor
Site selection factor
Average dust concentration in air Total hours of inhalation
NRC total diet assumption
NRC total diet assumption
NRC total diet assumption
NRC total diet assumption

Time delay factora

Waste form and package factor Volume of basement Bottom $1 \mathrm{~m}$ of excavation Top $2 \mathrm{~m}$ of excavation

Class $C$ wastes are assumed to reduce the impacts of intrusion scenarios by a factor of 10

a. Note: For Class A wastes the time delay is assumed to be 100 years, and for Class $C$ wastes it is assumed to be 500 years after waste burial. 


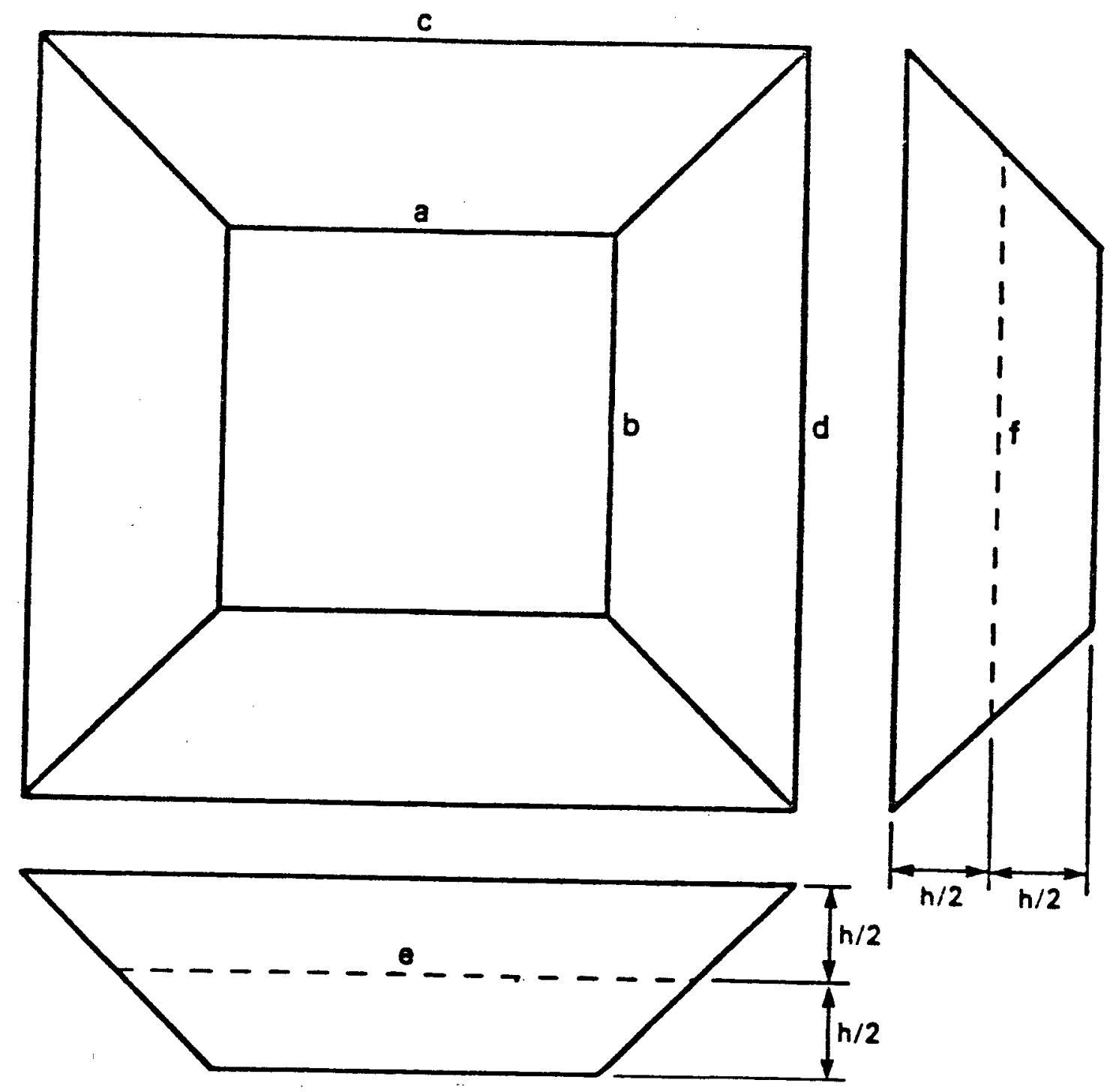

$$
\text { Volume }=\frac{h}{6}(a b+c d+4 e f)
$$

Figure 1. Intruder-construction basement excavation volume calculations (p. 4-23 of Reference 5). 
The factor, $f_{d}$, is the site design and operation factor and denotes dilution of the waste resulting from the particular disposal practice. Its value is assumed by the NRC to be 0.5 for random and decontainerized wastes, and 0.75 for stacked wastes.

The waste form and package factor, $f_{W}$, was included to allow for improved waste forms that may reduce intruder impacts by accounting for wastes that may be less dispersible or accessible. For the waste form no-credit option, $f_{W}$ for air is set to 1.0. For the direct gamma pathway, $f_{W}$ is the product of an accessibility multiplier and a solidification multiplier. The NRC set the accessibility multiplier to 1.0 for the no-credit option. The solidification multiplier is assumed to be 0.8 for solidified wastes, but for the no-credit option it is set to 1.0. The site selection factor, $f_{s}$, is different for the air and direct gamma pathways in the intruder-construction scenario. For the air pathway, it is the product of the soil-to-air transfer factor ( $T_{s a}$ ) and the exposure duration factor. The $T_{s}$ a is dependent on the environmental conditions of the region where the facility is located. The exposure duration factor is the fraction of a year that the construction takes place. For the case evaluated by the NRC, the exposure duration factor is $500 \mathrm{~h} / 8760 \mathrm{~h}$ (in a year), or 0.057 , and the site selection factor for air uptake is $2.01 \times 10^{-11}$ (p. G60 of Reference 7). For the direct gamma pathway, the site selection factor is equal to the exposure duration factor $(0.057)$.

Combining these factors for the intruder-construction scenario, Equation (1) would be rewritten with the constants shown as:

$$
H=\sum_{n}\left(1.01 E-11 f_{0}\right) \text { air } C_{W} \text { PDCF }-2+\sum_{n}\left(0.285 f_{0}\right){ }_{D G} C_{W} \text { PDCF }-5
$$

For the assessment of DOE LLW, the short-term exposure performance objective of 500 mrem effective dose equivalent applies to this scenario. Intruder-Agriculture Scenario

The second scenario used by the NRC in setting the Class $A$ and $C$ limits is the intruder-agriculture scenario. For this scenario, it is assumed that an intruder inadvertently lives on and consumes food grown on the disposal facility. Because farming does not involve penetrating the overburden at a 
closed site, this scenario is applied as an extension of the intruderconstruction scenario. The waste/soil mixture that is excavated during the basement construction activities of the intruder-construction scenario is assumed by the NRC to be used as backfill around the house and spread around the house to a radius of about $25 \mathrm{~m}$ ( $p . G-61$ of Reference 7 ). The intruder is then assumed to live in a house at this site and consume food products from a small garden located in the waste/soil mixture.

The NRC considered exposure through three major pathways for this scenario: (1) inhalation of air contaminated by the resuspended waste/soil mixture, (2) ingestion of garden products grown in the contaminated waste/soil mixture, and (3) direct exposure to gamma radiation. For the analysis of DOE wastes, the long-term exposure performance objective of an effective dose equivalent of $100-\mathrm{mrem} / \mathrm{yr}$ is used for this scenario.

The equation used by the NRC to describe the intruder-agricultural scenario is given as ( $p . G-62$ of Reference 7 ):

$$
\begin{aligned}
H= & \sum_{n}\left(f_{0} f_{d} f_{W} f_{s}\right) \text { air } C_{W} \text { PDCF-2 }+\sum_{n}\left(f_{o} f_{d} f_{W} f_{s}\right)_{\text {food }} C_{W} \text { PDCF-4 } \\
& +\sum_{n}\left(f_{0} f_{d} f_{W} f_{s}\right) D G C_{W} \text { PDCF-5 }
\end{aligned}
$$

Where

$$
\begin{aligned}
H & =\text { the } 50 \text {-year dose commitment in mrem } \\
\text { PDCF-2 } & =\text { pathway dose conversion factor for air } \\
\text { PDCF-4 } & =\text { pathway dose conversion factor for ingestion of garden crops } \\
\text { PDCF-5 } & =\text { pathway dose conversion factor for direct gamma exposure } \\
C_{W} & =\text { the concentration of radionuclide, } n, \text { in the waste. }
\end{aligned}
$$

The time delay factor, $f_{0}$, accounts for radioactive decay, and the site design and operation factor, $f_{d}$, is identical to the assumptions made by the NRC for the intruder-construction scenario. An additional factor of 0.25 is included by the NRC in the site design and operation factor to account for dilution resulting from mixing the diluted waste $\left(232 \mathrm{~m}^{3}\right)$ with the excavated cover soil $\left(680 \mathrm{~m}^{3}\right)$. Thus, the resulting value of $f_{d}$ for this NRC scenario is 0.125 . 
The waste form and package factors for the air uptake and direct gamma pathways, $f_{W}$, are the same as those assumed by the NRC for the intruderconstruction scenario [see Equation (1)]. For the food ingestion pathway, two options for the calculation of $f_{W}$ are available in the NRC model. However, for the waste form no-credit option, the $f_{W}$ is determined to be 1.0 . The NRC assumed specific dietary values in calculating the PDCF-4 values for ingestion of vegetables, meat, and milk.

The site-selection factor, $f_{s}$, for the air uptake pathway relies on the average of all activities conducted during the year (p. 4-33 of Reference 5). The overall estimate was calculated by the NRC by assuming that the air concentration for construction activities applies during the 100 hours of gardening activity, a dust loading of $0.1 \mathrm{mg} / \mathrm{m}^{3}$ applies during other outdoor activities, and an indoor air concentration of $0.05 \mathrm{mg} / \mathrm{m}^{3}$ applies for 4348 hours of indoor activities. For the NRC reference southeastern site, the time-weighted average of these values is $3.18 \times 10^{-11}$. The average dust concentration for all of the activities conducted during a year is $0.154 \mathrm{mg} / \mathrm{m}^{3}$. For the soil uptake pathway, $f_{s}$ (or the fraction of food consumed by the individual that is grown on site) is assumed by the NRC to be 0.5 .

For the direct gamma radiation pathway, $f_{S}$ is the product of the exposure duration fraction multiplied by a correction factor to account for the limited areal extent of the source and the limited time spent near this source. The NRC assumes that the intruder spends 1800 hours outdoors and 4380 hours indoors, with assumed shielding factors to account for source geometry and shielding from the house structure. The overall correction factor applied for the direct gamma pathway is 0.27 , accounting for exposure to a finite disk source while at home (on the waste site) .9

Combining these factors and parameters for the intruder-agriculture scenario, Equation (3) could be rewritten with the constants shown as:

$$
\begin{aligned}
H= & \sum_{n}\left(3.98 E-12 f_{0}\right) \text { air } C_{W} \text { PDCF }-2+\sum_{n}\left(0.0625 f_{0}\right) \text { food }_{W} C_{W} \text { PDCF }-4 \\
& +\sum_{n}\left(0.0338 f_{0}\right) \text { DG } C_{W} \text { PDCF }-5
\end{aligned}
$$




\section{Additional Intruder Scenarios}

In addition to varying parameters and assumptions based on site-specific conditions, the types of intruder scenarios considered may also vary depending on the wastes, engineering methods, and environmental conditions. For example, if wastes are processed into a special form (so that they resist human intrusion), or if they are buried at depths greater than $5 \mathrm{~m}$, the intruder scenarios defined by the NRC for surface excavation may not directly apply. Disposal with special waste forms or at depths greater than $5 \mathrm{~m}$ resembles the conditions anticipated for "Greater Confinement Disposal" operations for LLW at many of the operating DOE burial grounds. For these conditions, additional intruder scenarios must be defined. Two scenarios that should apply to most sites and disposal systems are the drilling and post-drilling scenarios. These scenarios were considered in Reference 8. Although this document does not address LLW directly, the near-surface storage of these wastes does approximate shallow-land LLW disposal. Because the volume of waste encountered during drilling is small compared to the volume of waste encountered during basement excavation, the individual doses resulting from drilling are generally smaller than for excavation. The following sections contain brief descriptions of these scenarios and the types of radiation exposure conditions that may be included in a site-specific performance assessment.

Drilling Scenario

Drilling through buried LLW means to penetrate the waste and remove waste and soil material up to the land surface. Drilling can occur during exploration for natural resources (i.e., oil, gas, or water) or as part of site characterization as required by the Comprehensive Environmental Response, Compensation, and Liability Act (CERCLA) or the Resource Conservation and Recovery Act (RCRA). Drilling is likely to penetrate the waste zone at all shallow-land burial sites, independent of the waste form, engineered barrier, or near-surface depth. The use of monuments, barriers, or markers can reduce the likelihood of drilling into a waste area, but it cannot preclude drilling. The total volume of waste brought to the surface during drilling is a function of the drill core diameter, the thickness of the waste disposal zone, and the time after disposal that the drilling is assumed to occur. For example, if a water well $0.3 \mathrm{~m}$ in diameter is drilled through a 5 -m-thick waste zone, the 
volume of waste brought to the surface is about $0.35 \mathrm{~m}^{3}$. This waste volume can expose the drilling crew through two major pathways: inhalation of resuspended material and direct exposure to penetrating radiation. The air concentration, dilution with non-active soils, and exposure duration will all be functions of site-specific conditions and the water-well drilling method used. For example, wash boring, jet percussion, cable-tool (percussion), and mud rotary drilling techniques all involve the use of water or a wet slurry that substantially reduces the airborne dust concentration. Previous assessments that include the drilling scenario have assumed about 1 hour to drill through the waste, an air concentration of $10^{-4} \mathrm{~g} / \mathrm{m}^{3}$, and external exposure to a distributed soil source (finite slab geometry) to last for up to 1 week.10

\section{Post-Drilling Scenario}

The post-drilling scenario is similar to the intruder-agriculture scenario defined by the NRC, because it considers the long-term exposures that result after wastes have been mixed with surface soils. This scenario has three major exposure pathways: inhalation of resuspended material, direct exposure to penetrating radiation, and ingestion of contaminated vegetables grown on the site. For this scenario, the volume (and quantity) of waste brought to the surface by the drilling scenario is assumed to be diluted with surface soil and spread around the site. Previous studies have considered uniform mixing of the wastes with the soil in the plow layer (the top $15 \mathrm{~cm}$ of soi1) and distribution over a $2500-\mathrm{m}^{2}$ area (Reference 10 ). Roughly $25 \%$ of an individual's diet could be grown in this area of contaminated soil. The individual is further assumed to spend a major portion of the year (up to 6 months) residing on the site. 
As a demonstration of the role of human-intrusion scenarios in LLW assessments, a series of example calculations are described in this section. Descriptions of the dose conversion factors used by both the NRC and the DOE are provided, followed by example unit dose calculations (relating the rem per $\mathrm{Ci} / \mathrm{m}^{3}$ for each scenario and radionuclide), and the results of generic waste classification calculations.

\section{Dose Conversion Factors}

The radiation doses calculated during a LLW performance assessment rely on the direct use of radiation dose conversion factors. There are two basic dosimetry systems that may be used for estimating radiation dose: the method described by the International Commission on Radiological Protection (ICRP) in their Publication $2^{11}$ and the newer methods described in ICRP 26 and $30.12,13$ The NRC used the methods of ICRP 2 and information from Appendix I of 10 CFR $50^{14}$ as the basis of their 10 CFR 61 waste classification system. The DOE requires the use of ICRP 30 effective dose equivalent factors for all public radiation dose calculations, including those resulting from $L L W$ performance assessments. The following paragraphs describe these factors and their use within intruder scenarios.

\section{NRC Pathway Dose Conversion Factors}

As shown in Equations (1) through (4), the NRC defined pathway dose conversion factors (PDCFs) to estimate radiation doses for the intruderconstruction and intruder-agriculture scenarios. These PDCFs account for air pathways (PDCF-2 and PDCF-3), food ingestion (PDCF-4), and direct gamma-ray exposure (PDCF-5), as shown in Figure 2 (Vol. 4, P. G-26, of Reference 7) for the intruder scenarios. A summary of the access location-to-human pathway descriptions provided by the NRC for the important intruder scenario pathways is given in Table 2 (Reference 9). The dose conversion factors used to produce the PDCFs are based on the methods of the ICRP as described in the ir Publication 2 (Reference 11).

Additional pathway assumptions are consistent with the information contained in Appendix I of 10 CFR 50 (Reference 14). Because the PDCFs 


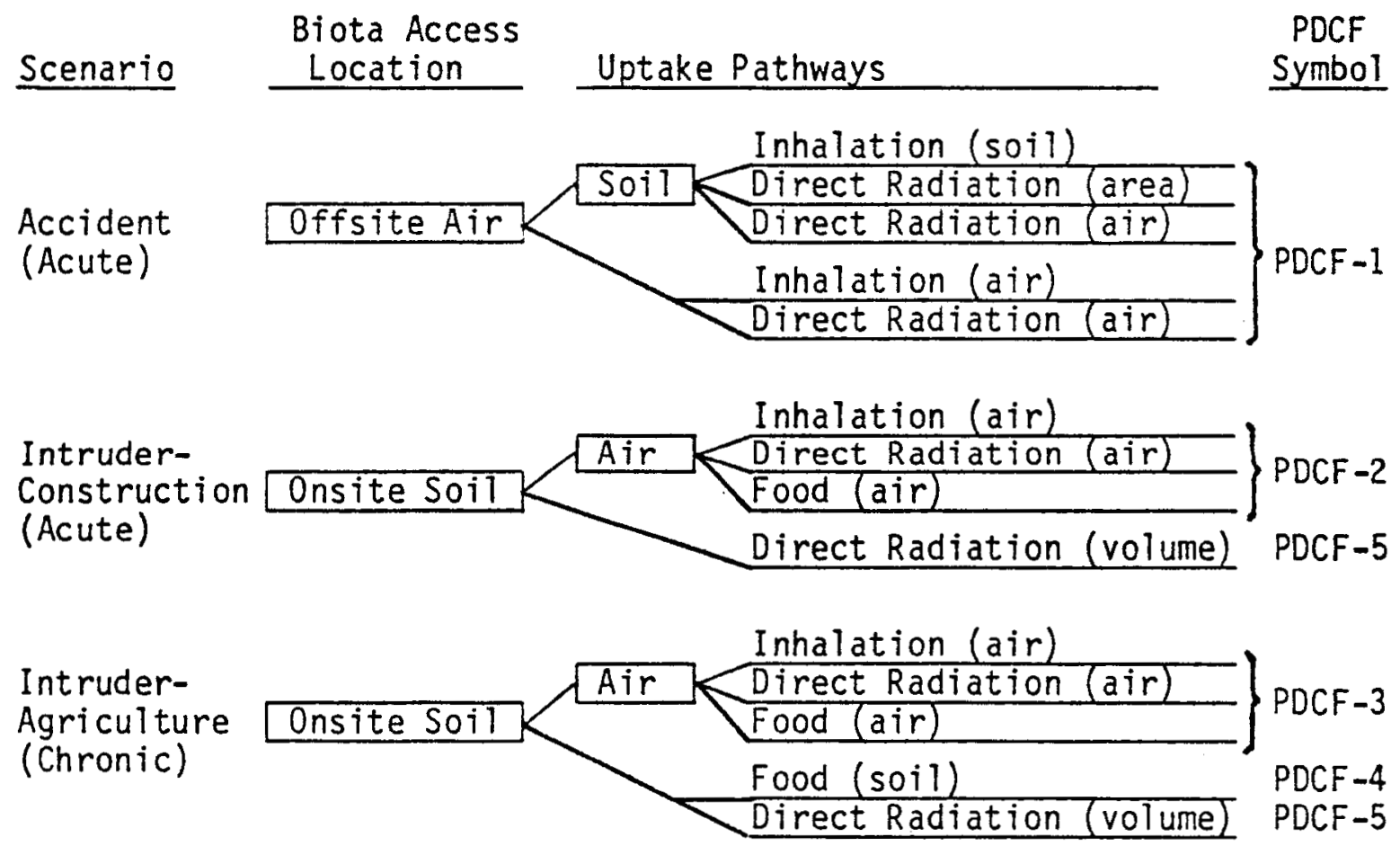

Figure 2. Details of uptake pathways (Reference 9). 
TABLE 2. ACCESS LOCATION-TO-HUMAN PATHWAY DESCRIPTIONS (Reference 9)

Pathway

Designation

Food (Soil)

Food (Air)

Inhalation (Air)

Direct Radiation

(Volume)

Direct Radiation (Air)

\section{Description}

This uptake pathway includes a total of three subpathways and denotes uptake of radionuclides origination in plants via soil-to-root transfer from contaminated soil:

$$
\begin{aligned}
& \text { plant-to-human } \\
& \text { plant-to-animal-to-human } \\
& \text { plant-to-animal-to-product-to-human }
\end{aligned}
$$

This uptake pathway includes a total of six subpathways and includes the above three food (soil) subpathways resulting from uptake of radionuclides originating on plant surfaces via deposition from contaminated air and the same three food (soil) subpathways resulting from fallout contamination of the ground

Uptake of radionuclides from breathing air contaminated due to suspension of contaminated soil particulates by human activities

Direct exposure to ionizing radiation from standing on ground homogeneously contaminated

Direct exposure to ionizing radiation from standing in air homogeneously contaminated 
represent combined "sub-pathways" that account for exposure by secondary means, they are difficuit to directly compare with single pathway modes of exposure. For example, the NRC PDCFs for the air pathway combine six "subpathways," including inhalation (of the plume and a resuspended dust cloud), direct radiation by air immersion (in the plume and a resuspended dust cloud), direct radiation from soil deposition, and ingestion of foods contaminated by deposition from the air.

\section{DOE Internal Dose Conversion Factors}

To assure consistency in all public radiation dose estimates performed for DOE operations, the DOE issued a document providing committed dose equivalent factors.15 The factors contained in this document are based on the most recent recommendations of the ICRP as found in ICRP 26, 30, and 48. 12,13,16 These dose conversion factors can be used to estimate doses from inhalation or ingestion of radioactive materials in units of effective dose equivalent. The effective dose equivalent is the summation of the products of the dose equivalent received by specified tissues of the body and a tissuespecific weighting factor. This sum represents a risk-equivalent dose that can be used to estimate the potential health effects to an individual or population group resulting from radiation exposure. The tissue-specific weighting factor represents the fraction of the total health risk resulting from uniform whole-body irradiation that would be contributed by that particular tissue.

\section{Example Unit Dose Calculations}

As a comparison of the magnitude of the doses resulting for the identified human-intrusion scenarios, example calculations were performed next. These calculations produced the effective dose equivalent, by radionuclide, for unit concentrations of radionuclides $\left(1 \mathrm{Ci} / \mathrm{m}^{3}\right)$ in the disposed $\mathrm{LLW}$. To produce the dose estimates, the ONSITE/MAXI1 (Reference 5) computer program was used with a library of the DOE internal effective dose conversion factors. The DOE internal dose conversion factors account for the effective dose equivalent resulting from a unit of intake either by inhalation or ingestion (Reference 15). To estimate the dose from direct exposure to penetrating radiation, dose conversion factors from the ONSITE/MAXI1 computer program 
were used (Reference 5). These factors model surface soil as being an infinite non-shielded slab source $1 \mathrm{~m}$ in thickness, with a density of $1.8 \mathrm{~g} / \mathrm{cm}^{3}$. These external dose factors and the PDCF-5 values used by the NRC generally agree (within a modeling factor of 2 to 5) for most radionuclides.

To use the DOE internal dose conversion factors, simplifications to the NRC PDCF method have been applied. The dose resulting from the major exposure pathways has been accounted for without the complexity of defining "subpathways." For example, the contribution from immersion in a contaminated cloud has been ignored, and the factor accounting for deposition from air on leaves has been included as part of the ingestion analysis for the intruderagriculture scenario only. The contribution from air immersion is generally only a few percent (typically less than $5 \%$ ) of the dose from the other pathways considered in a scenario analysis; thus, omitting air immersion should have a minor impact on the final answer. The dose contribution from air deposition on leaves of garden crops downwind from the site in the intruder-construction scenario is also ignored, because its dose contribution is only a few percent (typically less than 5\%) of the contribution from inhalation.

The unit doses produced during the example scenario analysis for representative radionuclides are shown in Table 3 for a decay period of 100 years and, for example, radionuclides in Table 4 for a decay period of 500 years. These decay periods were chosen to agree with the proposed institutional control period in draft DOE Order 5820.2A, Chapter III (100 years) and intruder-resistant disposal methods defined by the NRC for their Class $C$ wastes (500 years). The example radionuclides were selected because they were considered by the NRC in 10 CFR 61, or because they are potentially important in defense LLW streams. The doses listed in these tables are estimated to result 100 or 500 years after disposal of a unit concentration $\left(1 \mathrm{Ci} / \mathrm{m}^{3}\right)$ of each radionuclide shown. The doses are listed for the intruderconstruction, drilling, intruder-agriculture, and post-drilling scenarios. As previously discussed, no dose estimates are provided for the intruderdiscovery scenario, because it is considered to be a subset of the intruderconstruction scenario. The estimated doses in Table 3 do not include any credits for waste form or burial configuration, as described by the NRC, beyond the basic scenario description and the parameter values listed in Table 1. 
TABLE 3. DOSE PER UNIT CONCENTRATION EXAMPLE RESULTS FOR INTRUSION 100 YEARS AFTER SITE CLOSURE, REM/YR PER CI/M $3^{3}$

\begin{tabular}{|c|c|c|c|c|}
\hline Radionuclide & $\begin{array}{c}\text { Intruder- } \\
\text { Construction } \\
\end{array}$ & Drilling & $\begin{array}{c}\text { Intruder- } \\
\text { Agriculture }\end{array}$ & $\begin{array}{l}\text { Post- } \\
\text { Drilling }\end{array}$ \\
\hline $\begin{array}{l}3 \mathrm{H} \\
14 \mathrm{C} \\
60 \mathrm{Co}\end{array}$ & $\begin{array}{l}2.2 E-08 \\
3.2 E-04 \\
4.6 E-04\end{array}$ & $\begin{array}{l}4.8 E-12 \\
8.0 E-06 \\
4.1 E-04\end{array}$ & $\begin{array}{l}1.9 E-02 \\
1.8 E+02 \\
4.0 E-04\end{array}$ & $\begin{array}{l}3.0 E-04 \\
3.2 E+00 \\
1.1 E-04\end{array}$ \\
\hline $\begin{array}{l}59 \mathrm{Ni} \\
63 \mathrm{Ni} \\
90 \mathrm{Sr}\end{array}$ & $\begin{array}{l}5.9 E-05 \\
9.2 E-05 \\
5.6 E-02\end{array}$ & $\begin{array}{l}2.4 \mathrm{E}-08 \\
1.4 \mathrm{E}-07 \\
2.9 \mathrm{E}-03\end{array}$ & $\begin{array}{l}3.4 E-02 \\
5.1 E-02 \\
2.1 E+01\end{array}$ & $\begin{array}{l}4.8 E-03 \\
7.1 E-03 \\
3.0 E+00\end{array}$ \\
\hline $\begin{array}{r}94 \mathrm{Nb} \\
99 \mathrm{Tc} \\
129 \mathrm{I}\end{array}$ & $\begin{array}{l}1.5 E+02 \\
1.6 E-03 \\
1.2 E-01\end{array}$ & $\begin{array}{l}7.8 E+00 \\
6.0 E-06 \\
5.7 E-04\end{array}$ & $\begin{array}{l}1.3 E+02 \\
1.4 E+01 \\
8.8 E+01\end{array}$ & $\begin{array}{l}3.4 E+01 \\
2.0 E+00 \\
8.7 E-01\end{array}$ \\
\hline $\begin{array}{l}137 \mathrm{Cs} \\
238 \mathrm{U} \\
237 \mathrm{~Np}\end{array}$ & $\begin{array}{l}5.9 E+00 \\
1.2 E+01 \\
5.9 E+01\end{array}$ & $\begin{array}{l}3.3 E-01 \\
2.3 E-03 \\
3.6 E-02\end{array}$ & $\begin{array}{l}5.4 E+00 \\
1.1 E+01 \\
1.9 E+03\end{array}$ & $\begin{array}{l}1.4 \mathrm{E}+00 \\
1.1 \mathrm{E}+00 \\
1.3 \mathrm{E}+01\end{array}$ \\
\hline
\end{tabular}

a. No credit for waste form or burial configuration beyond the preceding scenario descriptions has been given. 
TABLE 4. DOSE PER UNIT CONCENTRATION EXAMPLE RESULTS FOR INTRUSION 500 YEARS AFTER SITE CLOSURE, REM/YR PER CI/M $3^{\text {a }}$

\begin{tabular}{|c|c|c|c|c|}
\hline Radionuclide & $\begin{array}{c}\text { Intruder- } \\
\text { Construction } \\
\end{array}$ & Drilling & $\begin{array}{l}\text { Intruder- } \\
\text { Agriculture }\end{array}$ & $\begin{array}{l}\text { Post- } \\
\text { Drilling }\end{array}$ \\
\hline $\begin{array}{l}3 \mathrm{H} \\
14 \mathrm{C} \\
60 \mathrm{Co}\end{array}$ & $\begin{array}{l}3.5 E-19 \\
3.1 E-05 \\
5.9 E-28\end{array}$ & $\begin{array}{l}7.7 \mathrm{E}-23 \\
7.7 \mathrm{E}-07 \\
3.1 \mathrm{E}-29\end{array}$ & $\begin{array}{l}3.1 E-13 \\
1.7 E+01 \\
5.1 E-28\end{array}$ & $\begin{array}{l}4.9 E-15 \\
3.0 E-01 \\
1.4 E-28\end{array}$ \\
\hline $\begin{array}{l}59 \mathrm{Ni} \\
63 \mathrm{Ni} \\
90 \mathrm{Sr}\end{array}$ & $\begin{array}{l}5.9 E-06 \\
4.5 E-07 \\
2.9 E-07\end{array}$ & $\begin{array}{l}2.4 E-09 \\
6.6 E-10 \\
1.5 E-08\end{array}$ & $\begin{array}{l}3.4 E-03 \\
2.5 E-04 \\
1.1 E-04\end{array}$ & $\begin{array}{l}4.8 E-04 \\
3.5 E-05 \\
1.6 E-05\end{array}$ \\
\hline $\begin{array}{r}94 \mathrm{Nb} \\
99 \mathrm{TC} \\
129 \mathrm{I}\end{array}$ & $\begin{array}{l}1.5 \mathrm{E}+01 \\
1.6 \mathrm{E}-04 \\
1.2 \mathrm{E}-02\end{array}$ & $\begin{array}{l}7.8 E-01 \\
6.0 E-07 \\
5.7 E-04\end{array}$ & $\begin{array}{l}1.3 E+01 \\
1.4 E+00 \\
8.8 E+00\end{array}$ & $\begin{array}{l}3.4 E+00 \\
2.0 E-01 \\
8.7 E-01\end{array}$ \\
\hline $\begin{array}{l}137 \mathrm{Cs} \\
238 \mathrm{U} \\
237 \mathrm{~Np}\end{array}$ & $\begin{array}{l}5.7 E-05 \\
1.2 E+00 \\
5.9 E+00\end{array}$ & $\begin{array}{l}3.2 E-06 \\
2.3 E-04 \\
3.6 E-03\end{array}$ & $\begin{array}{l}5.2 E-05 \\
1.1 E+00 \\
1.9 E+02\end{array}$ & $\begin{array}{l}1.4 \mathrm{E}+05 \\
1.1 \mathrm{E}-01 \\
1.3 \mathrm{E}+00\end{array}$ \\
\hline
\end{tabular}

a. These dose estimates include an intruder-resistant waste form credit, similar to the assumptions used by the NRC. Because of this credit, the doses shown are $10 \%$ of the doses estimated without the credit. 
The estimated doses in Table 4 do include an intruder-resistant waste form or barrier assumption similar to the one identified by the NRC. Because of this credit, the doses shown are $10 \%$ of the doses estimated without the credit.

As shown by the estimated doses in Tables 3 and 4 , the scenario resulting in the highest radiation doses varies between the intruder-construction scenario (for radionuclides with a significant external exposure or inhalation pathway) and the intruder-agriculture scenario (for radionuclides with a significant food-ingestion pathway). The drilling and post-drilling scenarios produce radiation doses that are generally several orders of magnitude smaller than the doses resulting from the intruder-construction and intruder-agriculture scenarios. This is a reasonable result because of the reduced quantity of waste encountered during the scenario (the volume of a drill core versus the volume of the basement of a house) and the reduced exposure duration.

These estimated doses are used to develop an example generic waste classification system, as described in the following sections.

\section{Example Generic Waste Classification}

The unit doses discussed in the previous section are next used as the basis for determining an example generic waste classification system. The calculations necessary are similar to the "inverse-type" calculations described by the NRC (Reference 7) using the DOE performance objectives that 1 imit individual dose to the intruders. For continuous exposures, relating to the intruder-agriculture and post-drilling scenarios, the DOE performance objective is an annual dose limit of 100-mrem effective dose equivalent. For short-term exposures, relating to the intruder-construction and drilling scenarios, the DOE performance objective is a dose limit of 500 -mrem effective dose equivalent. The "inverse-type" calculation simply determines the waste concentration $\left(\mathrm{Ci} / \mathrm{m}^{3}\right)$ that would result in the performance objective dose limit for the scenario considered. The procedure for the "inverse-type" calculation is to simply divide the appropriate dose limit (in rem) by the estimated dose per unit concentration (rem per $\mathrm{Ci} / \mathrm{m}^{3}$ ) from Tables 3 or 4 .

The results of the "inverse-type" calculations for the example radionuclides are shown in Tables 5 and 6 for decay periods of 100 and 500 years, respectively. Again, these tables contain the example waste 
TABLE 5. EXAMPLE WASTE CLASSIFICATION BY SCENARIO FOR INTRUSION AT 100 YEARS, CI/M3

\begin{tabular}{ccccc}
\hline Radionuclide & $\begin{array}{c}\text { Intruder- } \\
\text { Constructiona }\end{array}$ & Drilling & $\begin{array}{c}\text { Intruder- } \\
\text { Agricultureb }\end{array}$ & $\begin{array}{c}\text { Post- } \\
\text { Drilling }\end{array}$ \\
\cline { 2 - 4 } $3 \mathrm{H}$ & $2 \mathrm{E}+07$ & $1 \mathrm{E}+11$ & $5 \mathrm{E}+00$ & $3 \mathrm{E}+02$ \\
$14 \mathrm{C}$ & $2 \mathrm{E}+03$ & $6 \mathrm{E}+04$ & $6 \mathrm{E}-04$ & $3 \mathrm{E}-02$ \\
$60 \mathrm{Co}$ & $1 \mathrm{E}+03$ & $1 \mathrm{E}+03$ & $3 \mathrm{E}+02$ & $9 \mathrm{E}+02$ \\
$59 \mathrm{Ni}$ & $8 \mathrm{E}+03$ & $2 \mathrm{E}+07$ & $3 \mathrm{E}+00$ & $2 \mathrm{E}+01$ \\
$63 \mathrm{Ni}$ & $5 \mathrm{E}+03$ & $4 \mathrm{E}+06$ & $2 \mathrm{E}+00$ & $1 \mathrm{E}+01$ \\
$90 \mathrm{Sr}$ & $9 \mathrm{E}+00$ & $2 \mathrm{E}+02$ & $5 \mathrm{E}-03$ & $3 \mathrm{E}-02$ \\
$94 \mathrm{Nb}$ & $3 \mathrm{E}-03$ & $6 \mathrm{E}-02$ & $8 \mathrm{E}-04$ & $3 \mathrm{E}-03$ \\
$99 \mathrm{TC}$ & $3 \mathrm{E}+02$ & $8 \mathrm{E}+04$ & $7 \mathrm{E}-03$ & $5 \mathrm{E}-02$ \\
$129 \mathrm{I}$ & $4 \mathrm{E}+00$ & $9 \mathrm{E}+02$ & $1 \mathrm{E}-03$ & $1 \mathrm{E}-01$ \\
$137 \mathrm{Cs}$ & & & & $7 \mathrm{E}-02$ \\
$238 \mathrm{U}$ & $8 \mathrm{E}-02$ & $2 \mathrm{E}+00$ & $2 \mathrm{E}-02$ & $4 \mathrm{E}-02$ \\
$237 \mathrm{~Np}$ & $4 \mathrm{E}-02$ & $2 \mathrm{E}+02$ & $8 \mathrm{E}-03$ & $8 \mathrm{E}-03$
\end{tabular}

a. Based on the DOE short-duration exposure performance objective of a 500-mrem effective dose equivalent.

b. Based on the DOE continuous exposure performance objective of a 100-mrem effective dose equivalent. 
TABLE 6. EXAMPLE WASTE CLASSIFICATION FOR INTRUSION-PROTECTED WASTES AT 500 YEARS, CI/M3

\begin{tabular}{|c|c|c|c|c|}
\hline Radionuclide & $\begin{array}{c}\text { Intruder- } \\
\text { Constructiona }\end{array}$ & Drillinga $^{a}$ & $\begin{array}{l}\text { Intruder- } \\
\text { Agricultureb }\end{array}$ & $\begin{array}{c}\text { Post- } \\
\text { Drilling }\end{array}$ \\
\hline $\begin{array}{l}3 \mathrm{H} \\
14 \mathrm{C} \\
60 \mathrm{Co}\end{array}$ & $\begin{array}{l}1 E+18 \\
2 E+04 \\
8 E+26\end{array}$ & $\begin{array}{l}6 E+21 \\
6 E+05 \\
2 E+28\end{array}$ & $\begin{array}{l}3 E+11 \\
6 E-03 \\
2 E+26\end{array}$ & $\begin{array}{l}2 E+13 \\
3 E-01 \\
7 E+26\end{array}$ \\
\hline $\begin{array}{l}59 \mathrm{Ni} \\
63 \mathrm{Ni} \\
90 \mathrm{Sr}\end{array}$ & $\begin{array}{l}8 E+04 \\
1 E+06 \\
2 E+06\end{array}$ & $\begin{array}{l}2 E+08 \\
8 E+08 \\
3 E+07\end{array}$ & $\begin{array}{l}3 E+01 \\
4 E+02 \\
9 E+02\end{array}$ & $\begin{array}{l}2 E+02 \\
3 E+03 \\
6 E+03\end{array}$ \\
\hline $\begin{array}{l}94 \mathrm{Nb} \\
99 \mathrm{TC} \\
129 \mathrm{I}\end{array}$ & $\begin{array}{l}3 E-02 \\
3 E+03 \\
4 E+01\end{array}$ & $\begin{array}{l}6 E-01 \\
8 E+05 \\
9 E+02\end{array}$ & $\begin{array}{l}8 E-03 \\
7 E-02 \\
1 E-02\end{array}$ & $\begin{array}{l}3 E-02 \\
5 E-01 \\
1 E-01\end{array}$ \\
\hline $\begin{array}{l}137 \mathrm{Cs} \\
238 \mathrm{U} \\
237 \mathrm{~Np}\end{array}$ & $\begin{array}{l}9 E+03 \\
4 E-01 \\
8 E-02\end{array}$ & $\begin{array}{l}2 E+05 \\
2 E+03 \\
1 E+02\end{array}$ & $\begin{array}{l}2 E+03 \\
8 E-02 \\
5 E-04\end{array}$ & $\begin{array}{l}7 E+03 \\
9 E-01 \\
8 E-02\end{array}$ \\
\hline
\end{tabular}

a. Based on the DOE short-duration exposure performance objective of a 500mrem effective dose equivalent.

b. Based on the DOE continuous exposure performance objective of a 100 -mrem effective dose equivalent. 
classification values, by scenario, that result from a generic scenario evaluation. This generic evaluation provides a good comparison of the use of intruder scenarios in developing waste classification systems for defense LLW. The most restrictive waste classification values (lowest concentrations) result for the intruder-agriculture scenario for all of the example radionuclides considered in the generic calculations. This is partially because of the large dose-per-unit concentration values for this scenario and partially because of the use of the smaller (100 mrem) performance objective dose limit for continuous exposure.

When setting site-specific waste classification systems, an effort should be made to use those scenarios that realistically represent the potential future conditions for the waste, engineered system, and environment. For example, if a site disposes of wastes in standard steel drums (without an engineered waste form or package) in a standard shallow trench (without special intruderbarriers), the more restrictive of the intruder-construction and intruderagriculture scenarios or similar excavation scenarios would probably be used. However, if high-integrity waste forms or packages, or trenches with engineered barriers were used, the more restrictive of the drilling or post-drilling scenarios would probably be used to set the classification system.

\section{Example Mixture Analys is}

As an example of the application of waste classification to mixtures of radionuclides, an example calculation using the sum-of-fractions rule is next discussed. The sum-of-fractions rule can be applied to evaluate the radionuclides in any waste stream for compliance with site-specific waste classification systems: By this rule, the ratio of the concentration of each radionuclide in a mixture to its concentration limit, summed over all radionuclides in the mixture, must not be greater than unity.

For the example calculation, the waste classification system is assumed to be controlled by the intruder-agriculture scenario results shown in Tables 5 and 6 for 100 years and 500 years of decay. Again, the values in Table 6 include an intruder-resistant waste form credit similar to the one used by the NRC in their waste classification calculations. This credit reduces the dose-per-unit concentration values to $10 \%$ of what they would have been without 
the credit. This means that the waste classification values (in $\mathrm{Ci} / \mathrm{m}^{3}$ ) are 10 times larger because of the waste form credit. As an example of the application of the sum-of-fractions rule, the example mixture of radionuclides shown in Table 7 is considered. The listed radionuclide concentrations (in $\left.\mathrm{Ci} / \mathrm{m}^{3}\right)$, the ratio of these concentrations by radionuclide to the corresponding intruder-agriculture waste classification limits at 100 and 500 years, and the sum of these ratios over all radionuclides are also given in Table 7 .

For this example waste concentration, the example 100-year classification limits are exceeded because of the concentration of ${ }^{90} \mathrm{Sr}$ and ${ }^{137} \mathrm{Cs}$ in the mixture. The sum of the fractions for this mixture equals $410 ;$ clearly in excess of 1.0. However, the waste concentration for this example mixture easily meets the example 500-year intruder-resistant classification limits with a sum of the fractions of only 0.074 .

As an additional comparison, example calculations were performed for the reference waste mixture using the NRC Class $A$ and $C$ limits. The results of this comparison are shown in Table 8 . As is shown in the table, the NRC Class A limits are exceeded because of the presence of $90 \mathrm{Sr}$ and $137 \mathrm{Cs}$ in the mixture. The sum of the fractions for the NRC Class A comparison equals 46 . The NRC Class $C$ limits are met because the sum of the fractions equals 0.011 .

Although the example mixture results are similar for both the example DOE waste classification system and the NRC classification (i.e., the limits are exceeded at 100 years but not at 500 years), there are several reasons for developing DOE site-specific waste classifications systems. First, the DOE procedure requires the use of the dose conversion factors that are consistent with the most recent methods provided by the ICRP. Second, the DOE procedure requires consistency with $D O E / E H$ Orders that establish public radiation protection standards for all DOE operations. Third, site-specific calculations provide the flexibility to consider mixtures of radionuclides that may be quite different from the mixtures in commercial LLW considered by the NRC. Finally, by requiring site-specific waste classification systems DOE will assure that adequate modeling consideration is given to the long-term performance of waste forms, engineered barriers, and specific environmental conditions. 
TABLE 7. EXAMPLE CALCULATIONS FOR A REFERENCE WASTE MIXTURE USING THE EXAMPLE WASTE CLASSIFICATION LIMITS

\begin{tabular}{|c|c|c|c|}
\hline Radionuclide & $\begin{array}{c}\text { Example } \\
\text { Concentration, } \\
\mathrm{Ci} / \mathrm{m}^{3} \\
\end{array}$ & $\begin{array}{l}\text { Ratio to } \\
\text { the } 100-Y e a r \\
\text { Limita } \\
\end{array}$ & $\begin{array}{c}\text { Ratio to } \\
\text { the } 500-Y e a r \\
\text { Limitb } \\
\end{array}$ \\
\hline $\begin{array}{l}3 \mathrm{H} \\
14 \mathrm{C} \\
60 \mathrm{Co}\end{array}$ & $\begin{array}{l}2.0 E+00 \\
1.0 E-05 \\
5.5 E-01\end{array}$ & $\begin{array}{l}4.0 E-01 \\
1.7 E-02 \\
1.8 E-01\end{array}$ & $\begin{array}{l}6.7 E-12 \\
1.7 E-03 \\
2.8 E-27\end{array}$ \\
\hline $\begin{array}{l}59 \mathrm{Ni} \\
90 \mathrm{Sr} \\
129 \mathrm{I}\end{array}$ & $\begin{array}{l}5.0 \mathrm{E}-01 \\
1.8 \mathrm{E}+00 \\
5.0 \mathrm{E}-04\end{array}$ & $\begin{array}{l}1.7 E-01 \\
3.6 E+02 \\
5.0 E-01\end{array}$ & $\begin{array}{l}1.7 E-02 \\
2.0 E-03 \\
5.0 E-02\end{array}$ \\
\hline $\begin{array}{l}137 \mathrm{Cs} \\
238 \mathrm{U}\end{array}$ & $\begin{array}{l}1.0 E+00 \\
2.3 E-04\end{array}$ & $\begin{array}{l}5.0 E+01 \\
2.9 E-02\end{array}$ & $\begin{array}{l}5.0 E-04 \\
2.9 E-03\end{array}$ \\
\hline TOTAL & $6.0 E+01$ & $4.1 E+02$ & $7.4 \mathrm{E}-02$ \\
\hline
\end{tabular}

a. Based on compliance with example waste classification limits for the intruder-agriculture scenario listed in Table 5.

b. Based on compliance with the example waste classification limits for the intruder-agriculture scenario listed in Table 6. 
TABLE 8. EXAMPLE CALCULATIONS FOR A REFERENCE WASTE MIXTURE USING THE GENERIC EXAMPLE WASTE CLASSIFICATION LIMITS

\begin{tabular}{|c|c|c|c|}
\hline Radionuclide & $\begin{array}{c}\text { Example } \\
\text { Concentration, } \\
\mathrm{Ci} / \mathrm{m}^{3} \\
\end{array}$ & $\begin{array}{c}\text { Ratio to } \\
\text { NRC Class A } \\
\text { Limit } \\
\end{array}$ & $\begin{array}{c}\text { Ratio to } \\
\text { NRC Class C } \\
\text { Limit } \\
\end{array}$ \\
\hline $\begin{array}{l}3 \mathrm{H} \\
14 \mathrm{C} \\
60 \mathrm{Co}\end{array}$ & $\begin{array}{l}2.0 E+00 \\
1.0 E-05 \\
5.5 E+01\end{array}$ & $\begin{array}{l}2.9 E-03 \\
1.2 E-05 \\
7.9 E-02\end{array}$ & $\begin{array}{c}1.2 E-06 \\
-\end{array}$ \\
\hline $\begin{array}{l}59 \mathrm{Ni} \\
90 \mathrm{Sr} \\
129 \mathrm{I}\end{array}$ & $\begin{array}{l}5.0 E-01 \\
1.8 E+00 \\
5.0 E-04\end{array}$ & $\begin{array}{l}2.3 E-02 \\
4.5 E+01 \\
6.2 E-02\end{array}$ & $\begin{array}{l}2.3 E-03 \\
2.6 E-04 \\
6.2 E-03\end{array}$ \\
\hline $\begin{array}{l}137 \mathrm{Cs} \\
238 \mathrm{U}\end{array}$ & $\begin{array}{l}1.0 E+00 \\
2.3 E-04\end{array}$ & $\begin{array}{c}1.0 E+00 \\
-\end{array}$ & $\begin{array}{c}2.2 E-04 \\
-\end{array}$ \\
\hline TOTAL & $6.0 E+01$ & $4.6 \mathrm{E}+01$ & $1.1 E-02$ \\
\hline
\end{tabular}




\section{DISCUSSION}

As part of its revised Orders on LLW management, the DOE has established basic performance objectives that allow for the protection of the public and environment. To determine compliance with these performance objectives, draft DOE Order 5820.2A requires its operating defense LLW disposal sites to prepare and maintain a site-specific radiological performance assessment. As part of these performance assessments, the estimation of radiation dose resulting from human intrusion can be used to set site-specific limits on waste concentration, whereas evaluation of groundwater transport is useful in setting disposal quantity limits for a site. The concentration limits derived from human-intrusion scenarios are intended to serve as the basis of site-specific waste classification systems that also take into account other waste form and disposal design conditions. This report provides a useful discussion of intruder scenarios, example calculations that are useful in comparing the importance of the example scenarios for reference radionuclides, and example calculations that are useful in setting site-specific waste classification systems.

In support of the commercial LLW regulations, the NRC defined three intruder scenarios that served as the basis for their classification system. These scenarios were all initiated by a shallow excavation event (i.e., basement construction) and are noted as the intruder-construction, intruder-discovery, and intruder-agriculture scenarios. In addition to these excavation scenarios, scenarios that represent site-specific conditions should be evaluated as part of the DOE site-specific assessments. An example class of scenarios in addition to excavation involves drilling and post-drilling operations.

In establishing site-specific scenarios, attempts should be made to assure that the scenarios are representative of the likely events for the specific waste form and disposal technology encountered. The human-intrusion scenarios that are most often considered are deterministic; that is, they are simply assumed to occur without attempting to assign a probability to their occurrence. This approach is often used because of a lack of long-term performance data that can be used in a probabilistic analysis. Because deterministic analyses are performed, the scenarios, parameters, and assumptions should be "realistically 
conservative"; that is, they should be selected to reasonably overestimate the doses resulting from a given disposal system. This approach should assure compliance with the DOE LLW performance objectives, thereby assuring the safe disposal of defense LLW.

To better evaluate the potential impact of parameter uncertainty on performance assessment results, uncertainty analys is techniques have been developed.17 These techniques can be used with previously defined deterministic analyses to produce a probabilistic assessment. Assessments conducted in this manner may more realistically represent the range of potential outcomes without relying on assumed conservatism. If single results are desired, they may be produced by assuming an upper confidence limit.

Finally, the example results produced in this report for the various intruder scenarios were generated using the ONSITE/MAXI1 computer program (Reference 6). Similar results can be produced using a newer computer program developed for environmental pathway analysis that has an expanded user-friendly capability for establishing alternative scenario conditions - the GENII computer program.18 To obtain additional jnformation on intruder scenarios, alternative computer assessment methods, or site-specific data selection, please contact the authors or Mr. B. A. Napier at Pacific Northwest Laboratory, Richland, Washington 99352. 


\section{REFERENCES}

1. U.S. Code of Federal Regulations (CFR). 1987. National Emission Standard for Radionuclide Emissions from Department of Energy (DOE) Facilities. Title 40, Part 61 (40 CFR 61, Subpart H), U.S. Government Printing Office, Washington, D.C.

2. Case, M. J., and M. D. Otis. 1988. Guidelines for Radiological Performance Assessment of DOE Low-Level Radioactive Waste Treatment, Storage, or Disposal Sites. DOE/LLW-62T (DRAFT), National Low-Level Radioactive Waste Management Program, Idaho Falls, Idaho.

3. U.S. Code of Federal Regulations (CFR). 1986. Licensing Requirements for Land Disposal of Radioactive Waste. Title 10, Part 61 (10 CFR 61), U.S. Government Printing Office, Washington, D.C.

4. Nuclear Energy Agency of the Organization for Economic Cooperation and Development (NEA/OECD). 1987. Shallow Land Disposal of Radioactive Waste: Reference Levels for the Acceptance of Long-Lived Radionuclides. A report by an NEA Expert Group, Paris, France.

5. Oztunali, 0. I., and G. W. Roles. 1986. Update of Part 61 Impacts Analys is Methodology. NUREG/CR-4370, Vol. 1, U.S. Nuclear Regulatory Commission, Washington, D.C.

6. Kennedy, W. E., Jr., R. A. Peloquin, B. A. Napier, and S. M. Neuder. 1987. Intruder Dose Pathway Analys is for the Onsite Disposal of Radioactive Wastes: The ONSITE/MAXII Computer Program. NUREG/CR-3620 (Supplement 2): U.S. Nuclear Regulatory Commission, Washington, D.C.

7. U.S. Nuclear Regulatory Commission (NRC). 1981. Draft Environmental Impact Statement on 10 CFR 61 , "Licensing Requirements for Land Disposal of Radioactive Waste." NUREG-0782, Vols. 1-4, U.S. Nuclear Regulatory Commission, Washington, D.C.

8. U.S. Department of Energy (DOE). 1987. Final Environmental Impact Statement: Disposal of Hanford Defense High-Level, Transuranic, and Tank Wastes. DOE/EIS-0113, Vols. 1-5, U.S. Department of Energy, Washington, D.C.

9. Oztunali, 0. I., G. C. Re, P. M. Moskowitz, E. D. Picazo, and C. J. Pitt. 1981. Data Base for Radioactive Waste Management. NUREG/CR-1759, Vol. 3 , U.S. Nuclear Regulatory Commission, Washington, D.C.

10. Kennedy, W. E., Jr., B. A. Napièr, and J. K. Soldat. 1983. "Advanced Disposal Systems for Transuranic Waste: Preliminary Disposal Criteria for Plutonium-239 at Hanford." Nuclear and Chemical Waste Management, $4(1): 103-111$. 
11. International Commission on Radiological Protection (ICRP). 1959. Report of ICRP Committee II on Permissible Dose for Internal Radiation. ICRP Publication 2, Pergamon Press, New York, New York.

12. International Commission on Radiological Protection (ICRP). 1977. Recommendations of the International Commission on Radiological Protection. ICRP Publication 26, Pergamon Press, New York, New York.

13. International Commission on Radiological Protection (ICRP). 1979-1983. Limits for Intakes of Radionuclides by Workers. ICRP Publication 30 , Part 1 (and subsequent parts and supplements), Vol. 2, No. 3/4 through Vol. 8, No. 4, Pergamon Press, New York, New York.

14. Calculation of Annual Doses to Man From Routine Releases of Reactor Effluents for the Purpose of Evaluating Compliance with 10 CFR Part 50 , Appendix I, 1977. 10 CFR 50, Appendix I, U.S. Government Printing Office, Washington, D.C.

15. U.S. Department of Energy (DOE). 1988. Internal Dose Conversion Factors for Calculation of Dose to the Public. DOE/EH/0071, U.S. Department of Energy, Washington, D.C.

16. International Commission on Radiological Protection (ICRP). 1986. The Metabolism of Plutonium and Related Elements. ICRP Publication 48, Vol. 16, No. 2/3, Pergamon Press, New York, New York.

17. Farris, W. T. 1988. Probabilistically Derived Concentration Limits for Near-Surface Disposal of Radioactive Waste. Master of Science Thes is in Radiological Sciences, University of Washington, Seattle, Washington.

18. Napier, B. A., R. A. Peloquin, D. L. Strenge, and J. V. Ramsdell. 1988. Hanford Environmental Dosimetry Upgrade Project. GENII - The Hanford Environmental Radiation Dosimetry Software System. Volume 1: Conceptual Representation, Volume 2: Users' Manual, Volume 3: Code Maintenance Manual. PNL-6584, Pacific Northwest Laboratory, Richland, Washington. 